\title{
The Contemporary Dystopian Reality of Slavery and Modern Capitalism in Octavia Butler's Parable Novels
}

\author{
Cr Patricia Mary Hodge \\ Research Scholar, Department of English, NEHU. E-mail: patclhodge93@gmail.com, Orcid \\ id: 00oo-0002-3786-806o
}

\begin{abstract}
Critical dystopia as an analytic category for historical enquiry explores contemporary reality and its specificities in time and space. It functions as anagnorisis or recognition of the dystopian realities in the present through its generic mode of familiarising the heightened dystopian elements of the text as possible evolutions of current oppressions. This paper suggests that this anagnorisis through comparison and extrapolation is limited and needs to consider how the text ironically reveals the absence of historical specificity through its comparison of the contemporary present and the imagined future. Instead, specificity is replaced with a linear historical trajectory where dystopia occurs cyclically in metamorphosed forms within a fixed, yet evolving power-structure. This projects the nature of the dystopia in the text part of an evolutionary process, not a product of its historically specific period. Through the interrogation of how the legally abolished system of slavery is historically shifted into the future hyper-capitalist market system in Octavia Butler's Parable novels, this paper will reveal how the anagnorisis of the novels functions to locate dystopia as present and evolving in a historical trajectory of cyclical structural repetition. This familiarisation of the historical event of slavery in the novels posits the dystopian text's anagnorisis as not simply the recognition of dystopian elements specifically in the present but broadens it to the recognition of the historical evolution of those same human atrocities that appear to 'resurge' in dystopia.
\end{abstract}

Keywords: Slavery, capitalism, dystopia, anagnorisis

Aristotle's concept of anagnorisis, of a change from ignorance to knowledge, is expanded upon in the genre of dystopian fiction. Dystopian anagnorisis allows for the revelation of and the recognition of the existing dystopian correlative of the text in contemporary reality. Dystopian fiction typically achieves this recognition by looking back critically towards the authorial present from its imagined historical future. Dystopia's critical sensibility looks beyond the authoritarian state and reveals the contemporary depredated condition of diminished humanity that is embedded in a culture determined by the historical political-economic force. This invites the reader to recognise the systemic evils of the present and actively engage in the reconstruction of the future through the remediation of the present. In this mode of anagnorisis, dystopia's imaginary "elsewhere" is recognised to be real and in the present. Butler's Parable series functions in the mode of dystopian anagnorisis in that it reveals the truth of existing systemic evils which are articulated in political, social and cultural dimensions, in particular those social and ecological conditions caused by a hyper-capitalist economy. Butler achieves this recognition by familiarising the historical event of slavery with existing elements in the contemporary political-economic order, specifically through the resurgence of chattel slavery alongside contemporary forms of slavery in a futuristic version of the current political-economic system. Dubey (2013) states that slavery in Parable "appears more centrally as a descriptor of the present than as a historical (c) AesthetixMS 2020. This Open Access article is published under a Creative Commons Attribution Non-Commercial 4.o International License (http://creativecommons.org/licenses/by-nc/4.o/), which permits non-commercial re-use, distribution, and reproduction in any medium, provided the original work is properly cited. For citation use the DOI. For commercial re-use, please contact editor@rupkatha.com. 
reference point." (p. 358). She disrupts and decentres the realism of the established narrative of the historical institution of slavery by letting it intrude into the present and future, through memory, legacy and as a modern metamorphosed institution.

Butler successfully achieves the intended recognition of "where we are now, what we are doing now, and to consider where some of our current behaviours and unattended problems might take us" through the extrapolative nature of dystopian fiction (Butler, 2007, p. 337). The problem with the readings of dystopian narratives as merely extrapolation is that it can overshadow how the historical trajectory of the narratives moves beyond the present-future relationship. The generic convention of the dystopia means that it exists in a time frame that begins in the authorial present and ends in the future where the narrative is set in. This positions the period between the authorial present and the future dystopia as both future and the past, thus extending the dystopian existence to this undisclosed in-between period which Adam Stock (2016) refers to as "future-as-past" (p. 417). Based on Stock's concept of such a temporal continuity, along with dystopian anagnorisis and extrapolation, this relationship can naturally be extended to the historical past that precedes the authorial present. This complex temporality of dystopian fiction is critically employed concerning the political content generated by the unacknowledged past, the authorial present and the absentee future-as-past in the narrative of the imaginary future. The absence of fixed time-lines of difference and demarcation in the trajectory of the movement of the past into the future and the extrapolative nature of dystopian fiction posits dystopian realities as extant in the underbelly of human history.

Stock also notes that much of the reader's participation in the construction of the future depends upon guesswork and limited contextual knowledge due to the absence of the future-aspast in the novels (p. 417). He notes that this fragmentation disrupts the reader's ability to properly reconstruct the narrative of future history. This fragmentation of history that can estrange the reader from the future is usually resolved through moments of anagnorisis when allusions are made to the future-as-past and juxtaposed with the future to satirise the present. This process points to a pattern in the trajectory of history where dystopian elements evolve under the political and historical reality of the moving times. The recognition of the present in the future and the future in the future-as-past alludes to a cyclical pattern of resurged visibility of dystopian elements in their historically specific forms. Therefore, the narrative of the Parable series appears to hint at the possible resurgence of slavery to exploit populations for labour with the hyper-capitalist takeover of democracy. This reading fits perfectly with the extrapolative nature of dystopian fiction and the anagnorisis it provides regarding the contemporary capitalist structure. However the displacement of antebellum slavery from its historically specific period and sudden appearance in a post-civil war, post-segregation setting alludes to a combination of political, social and economic forces which allowed the legally abolished institution to fester below the surface until it finally supposedly 'resurged'. This understanding leads to the actual anagnorisis of the novels, which is that slavery did not 'resurge' but that it had finally become became visible because it had cyclically returned to its most recognisable form.

In the Parable of the Sower Lauren is repeatedly confronted with the reality of the existence of slavery. While she accepts this, she views these instances as natural consequences of social dystopia. She connects the existence of debt slavery and the human trafficking industry as problems caused by the growing problem of poverty, the corruption of authority, the weakening of the Constitution and the break-down of law and order. This is what Butler attempts to show readers: that for the modern population, slavery can only exist in dystopia, thus blinding people from the reality of its existence in contemporary reality. Lauren's knowledge of slavery is limited 
to the images and stories of plantation workers and domestic help in antebellum America. When she first meets Travis and Natividad, she finds herself unconsciously comparing them to antebellum period slaves because they were domestically employed in a white-house-hold. They fulfil all the stereotypes necessary for Lauren to equate them with antebellum period slaves. Travis's mother was employed in the same household, thereby making the family permanent inherited property. Travis reveals that his mother would sneak books from her employer's library. Lauren thinks of this effort on her part to educate her son, "Of course. Slaves did that two hundred years ago." (Butler, 2007, p. 218). Of Travis's marriage to Natividad, she thinks, "The son of the cook marrying one of the maids. That was like something out of another era, too." (p.219). She equates slavery with white masters who exploit their maids and mistresses who either turn a blind eye or, in some rare cases, sympathise with their poor maids. It is when Travis reveals that they chose to leave their employment that Lauren ends this association because actual slaves would never have been allowed to leave freely. She wonders, "How far did masters and mistresses go these days toward putting less than submissive servants in their place?" (p. 219). Slavery, even in the world-view of a Black woman, is rooted so deeply in its historical specificity of the institution in antebellum America that even the knowledge of its modern existence cannot severe this connection. According to this understanding of historical specificity, slavery cannot evolve into new forms at all because it cannot be separated from its established historical context.

Lauren does not make these automatic connections with institutionalised slavery when she initially meets Emery and Grayson who are fugitive debt-slaves. She slowly learns that the debt-slavery system shares many of the horrors of antebellum slavery, from the separation of families, the use of physical and psychological torment, white slave drivers and Black/Hispanic/Asian/ mixed-race 'workers' and the legal inability to leave the master/employer. Before meeting Emery, the concept of debt-slavery had been to Lauren more like a historical phenomenon, much like antebellum slavery, and the Rev's equation of both types of slavery was treated as hyperbole. Lauren comments, "Cities controlled by big companies are old hat in science fiction."(2007, p. 123). In this moment of self-recognition, the novel itself acknowledges its speculative genre and the problems of the imaginary and the real that come along with it. There is a wide disconnect between the past and the present in how Lauren views slavery as something that has died and is resurging again in new forms only as a consequence of a new exploitative economic system. This limits her understanding of the myriad of ways that slavery can operate as an institution. What Lauren does not recognise is the metamorphosis of the institution of slavery has been occurring throughout modern history in the shadows of the policy of neo-liberal capitalism.

Butler challenges the initial view of the historical specificity of slavery that her protagonist holds and instead acknowledges the contemporary reality of servitude and class discrepancies. She does so by using the critical extrapolative function of her dystopian texts to heighten presentday political-economic practices into dystopian tyranny, while also maintaining dystopian beginnings in the pre-authorial past. To achieve this recognition, Butler establishes a dialogic relationship between the past and the present, by examining 'freedom' in the modern context through an engagement with the narrative of emancipation or the 'freedom' narrative, all while interpreting history through the lens of the unrepresented. The migration to the north, for instance, is a modern retelling of the underground railway that led Frederic Douglas and Harriet Jacobs to their freedom. Lauren comments that their group has evolved into "the crew of a modern underground railway" with the addition of fugitive slaves like Emery and Grayson (2007, p. 292.). Stillman (2003) remarks that this migration to the north recalls both the history of slave fugitives escaping to the north and the modern phenomena of immigrants crossing the border 
into the United States. (p. 23). The journey is also a compelling tale of the contemporary myth of freedom in America that awaits the immigrant from the poorer periphery nations inhabited mainly by those dark-skinned populations that were once enslaved or colonised. This large scale migration based upon economic reasons, which is unique to capitalism, is reminiscent of the transport of thirty-million African slaves across the Atlantic Ocean to the New World. Butler asserts that the ideology of racial superiority that sustained colonialism and capitalism has cemented itself in contemporary unequal global political-economic relationships She illustrates this through her description of the crowd of people, of disposable labour travelling as a "heterogeneous mass-black and white, Asian and Latin. . . "(2007, p. 176). The moments of rupture in the comparison of the past and the future through the appearance of the familiar issues of immigration and the saturated employment throw light upon the continuities that also exist between the past and the present. The vigilant observation of the 'real' in dystopia brings to the foreground the reality of the existence of dystopian elements that sustain the utopia of a capitalist economy of unlimited choices.

In two instances in the Parable of the Sower, Butler shifts the focus from the past and the future directly to the present and incriminates contemporary neo-liberalism for its role in sustaining slavery. Both these instances are in the form of conversations with the older Black generation who have experienced life before the dystopia in the novels. The first instance is the Rev's exposition of company-towns and debt slavery as historical repetitions of the old company town system of late-nineteenth-century capitalism. As the economy rapidly declines, multinational conglomerates take over entire cities, privatise them and use the population as a labour source. The Rev asserts the possibility of debt slavery becoming reality through the state-capitalist nexus given the disintegration of labour, state and federal laws. Here Butler points to the continuation in the historical trajectory of slavery by linking chattel slavery with both historical capitalism and contemporary global economic slavery. In the second instance, Bankole asserts to Lauren that slavery did not suddenly resurge, but had always existed in different forms when Lauren's daily associations with the ex-debt slaves cause her to muse upon the sudden reappearance of slavery. She says, "Slavery again - even worse than my father thought, or at least sooner. He thought it would take a while." Bankole replies, "None of this is new." (2007, p. 292). He recalls how in the 1990s, when he was in college, growers in the south were already enslaving the Latino and Black community, "holding people against their wills and forcing them to work without pay." (p. 292). Here Butler effectively links the plantation slave legacy of the American south and the contemporary reality of the employment of undocumented immigrants as cheap farm labour in mainly white-owned avocado and citrus farms of the south. Butler is essentially contradicting the assumption that slavery is a thing of the past by referring to these examples of slavery that had metamorphosed to fit into trans-generational history. In doing so, she asserts that twenty-first-century slavery was not born in a vacuum, but is instead part of a linear historical trajectory where it cyclically manifests itself in new forms. This shifts the focus directly onto the present, leading readers to question how slavery has metamorphosed in the twentieth century.

Francis Fukuyama (1992) posits that history as an evolutionary process has ended with the global legitimacy of the intertwined political-economic ideologies of liberal democracy and capitalism. (pp. xi-xii). He argues for "the endpoint of mankind's ideological evolution and the universalisation of Western liberal democracy as the final form of human government." (1989, p. 1). Butler contests this through the repeated comparisons between old and new types of slavery which function to dismantle the meta-narrative of the triumphs of capitalism and globalisation. In the novels, modern utopian possibilities through political governance and economic prosperity 
end catastrophically when traditional American capitalism fails. As a narrative framework, the United States functions as a microcosm of the contemporary dystopian reality of slavery. In contemporary times, "first world" nations like the United States use subsidiaries to benefit from the lower labour cost of slave labour in peripheral developing and "third world" nations. In the late capitalism of the novels, the United States finds its slaves within its territory. Slavery thus continues to exist as an unregulated system of labour as companies are involved in systems of supply chains and labour conditions that violate human rights. Kevin Bales (1999) states in his seminal work on modern slavery, "There are more slaves alive today than all the people stolen from Africa in the time of the transatlantic slave trade.”(p. 9). According to the International Labour Organisation (2017), there is an estimated 40.3 million modern slaves in the world, with a large section enslaved in forced labour in both private and public sectors, and held in debt bondage exploited in forced labour imposed by state authorities. (pp. 9-11). Slavery has evolved from the transatlantic trade and tobacco, sugar and coffee plantations to global trafficking and prostitution, warehouses in "third-world" nations, indentured slavery in Mauritiana, bonded labour in India and Pakistan, immigrant sweatshops in Los Angeles and New York, among other examples. Slavery survives because of the constructed otherness of the enslaved, whether it is racial and ethnic as predominant in old slavery or the added parameters of differences of economic class, language, nationality etc. in its contemporary metamorphosis. Butler makes it clear that the acceptance of a temporal distancing from slavery and its strict definition of legal ownership can blind us to the various forms in which it persists today.

To achieve this anagnorisis, Butler constantly mediates between the past, the present and the future, using memory and legacy to trace the historical trajectory of slavery. In the process, she dissolves those boundaries that dismiss the historical repetition of human atrocities. She also reveals how modern slavery involves a recoding of race in a multi-racial and cultural world by assimilating mainly the underprivileged, non-white population into a pool of labour through economic coercion. On the surface, the common denominator that enables slavery in the novels appears to be poverty and not race. However, economic disparity exists in conjunction with racial differences, especially in the contemporary global economy born out of the colonial-capitalist conjunction. Stillman (2003) notes on the dystopia in the novels, "The new American dystopia stems from extremes of economic wealth and consequent inequality of political power so that the private power of the rich and of corporations dominates." (p. 17). Butler makes it clear that there is a correlation between race and poverty that has been perpetrated by a capitalist system with its roots in colonialism and slavery. This once again places slavery, which has been designated a fixed historical presence in the past, as extant and evolving in a historical trajectory into its current form in a neo-liberal capitalist political-economic order. In doing so, Butler uncovers how the institution of slavery was logically extended to race for economic reasons, and now includes new notions of race in a multi-racial world to encompass modern economic interests. History repeats itself as the purity of race and the exclusion, slavery and annihilation of "others" become the political goals and agenda to "make America great again."(Butler, 2016, p. 31).

This peculiar combination of the linear temporality of slavery and the cyclical pattern of oppression of the already marginalised, which Ellison (1982) metaphorised as the "boomerang" of history (p.5) is substantiated in the evolution of twenty-first-century slavery. The past, present and future finally collide for Lauren and the reader in two crucial moments of anagnorisis in the Parable of the Talents. Slavery has to reveal itself in the form that it is recorded in history for it to be truly recognisable to both the characters and the reader. The first instance is when Lauren is confronted by the image of her brother Marcus, a black man, shackled, collard and put up for sale. This is when Lauren truly acknowledges the truth that slavery is real and alive. In a perverted 
retelling of history, Lauren is compelled to buy her brother in a private slave auction. It is important to note that before meeting Marcus, Lauren had only heard tales of economic forms of slavery occurring in the near past from her father and Bankole or stories from ex-debt slaves. This accounts for her inability to actually recognise that the modern types of slavery are not new, but current versions of an institution that constantly metamorphoses to suit the needs of the time. This is also reflective of the reader's inability to creatively structure the dystopian future because of the lack of a contextualising historical framework to understand how exactly dystopia happened. The negotiation with slavery that Lauren finds herself engaged in is symptomatic of the modern condition. This dis-attachment of contemporary society from slavery is what caused societies to accept the legacy of slavery, yet blinds them to its systemic and structural presence.

The second instance is the forced enslavement of the residents of Acorn in the Parable of the Talents. It is when she experiences antebellum period slavery in its antithetical modern setting that Lauren realises that slavery never simply died and then resurged. It had always existed in various forms across history and she is the middle of a cyclical resurgence of that institutionalised form that specifically existed in her nation's history. In a retelling of the history of colonialism and slavery, Acorn is invaded by Christian fundamentalists who forcibly enslave the mixed-race, mainly Black and Latino, community. This enslavement of 'free' citizens is completely illegal but allowed to happen: the collaring of non-criminals, the confiscation of legally owned property, the separation of married couples and the forced, unpaid labour, forced indoctrination and sexual exploitation. The history of colonial and plantation slavery is thus revived through economic, religious and political justifications. Modern slavery at Acorn is justified because slavery is equated to rehabilitation and welfare in the same way that it is justified in capitalist labour supply chains as employment. It is after the modern ex-slaves are returned to slavery of the historical kind and Lauren inherits the racial trauma of slavery that the institution is doubly established through legacy and metamorphoses in a cyclical pattern within a linear historical trajectory.

Dystopian fiction's extrapolative nature accounts for its anagnorisis of the present, but the absence of the influencing power of the past that has constructed all present structures and ideologies leaves out crucial understandings of the dystopian understanding. This can hamper the anagnorisis that the dystopian text strives to attain because contextual and historical issues are necessary to arrive at a complete understanding of why imagined dystopias are so close to contemporary reality. Butler creatively facilitates mobility in time-space by bringing history into the present through the co-existence of traditional antebellum slavery and modern economic slavery and disables her characters from escaping this reality, even temporarily. Linking the past with the future forces the reader to investigate the role of the present in this relationship, allowing for the achievement of the crucial anagnorisis to break out of the passivity of political and socially sanctioned reality and also dismantle the closure of the historical narrative. The knowledge of the historical repletion of human atrocities and how this is enabled by the politicaleconomic system also provides a contemporary context to how and why capitalism can be linked to social and environmental dystopia. The predictions that arise out of the mere recognition that dystopian fiction is, "largely the product of the terrors of the twentieth century," (Moylan, 20oo, xii) is not enough to understand the cultural implications of the present upon the future. Instead, the recognition of the realism of dystopia can be arrived at through an engagement with both historical and contemporary reality to map the trajectory of the quiet evolution of dystopia across human history. Dystopia is therefore not the product of its specific historical factors, nor is it only a consequence of the unresolved problems of contemporary reality. Dystopia is instead the revelation of the amalgamation of elements of control, dominance and oppression in the basic 
structure of human organisation, regardless of what the political ideology of different historical periods may be. The Parable series allows for an in-depth look into this nature of the dystopian text through its dealings with an institution which has been archived as a historical event, disowned of its connections with democracy and capitalism and declared incapable of existing in a neo-liberal capitalist global economy. Butler establishes a historical trajectory that is not based upon historically specific timelines, but instead upon the historical experiences of oppression of the underrepresented in history, thereby decentering historical specificities as well as the metanarrative of equality in democracy. In doing so, she implicates the entirety of human history when she answers that self-reflexive dystopian question of how humanity arrived at dystopia.

\section{References:}

Butler, O. (2007). Parable of the Sower. Grand Central Publishing. (Original work published 1993).

Butler, O. (2016). Parable of the Talents. Grand Central Publishing. (Original work published 1993).

Bales, K. (1999).Disposable_People_New_Slavery_in_th(BookZZ.org).pdf (p. 158).

Dubey, M. (2019). Octavia Butler's Novels of Enslavement. 46(3), 345-363. https://doi.org/10.1215/o02951322345786

Ellison. R. (1982). Invisible Man. Random House.

Fukuyama, F. (1989). The End of History? The National Interest, 1-18.

Fukuyama, F. (1992). The End of History and the Last Man. In The End of History and the Last Man. The Free Press. https://doi.org/10.4324/9781912282135

International Labour Organisation and Walk Free Foundation. (2017). Global Estimates of Modern Slavery. Forced Labour and Forced Marriage. International Labour Office. https://www.ilo.org/wcmsp5 /groups/public/---dgreports/---dcomm/documents/publication/wcms_5 75479.pdf

Moylan, T. (2000). Scraps of the Untainted Sky: Science Fiction, Utopia, Dystopia. Westview.

Stillman, P. (2003). Dystopian Critiques, Utopian Possibilities, and Human Purposes in Octavia Butler's Parables. Utopian Studies, 14(1), 15-35.

Stock, A. (2016). The Future-as-Past in Dystopian Fiction. Poetics Today, 37(3), 415-442. https://doi.org/10.1215/o3335372-3599495

Cr Patricia Mary Hodge is a Research Scholar in the Department of English at the North-Eastern Hill University, Shillong, Meghalaya. Her area of research and interest include eco-feminism, ecospirituality, ecotopia, dystopia, post and transhumanism particularly in the genre of feminist speculative fiction. 